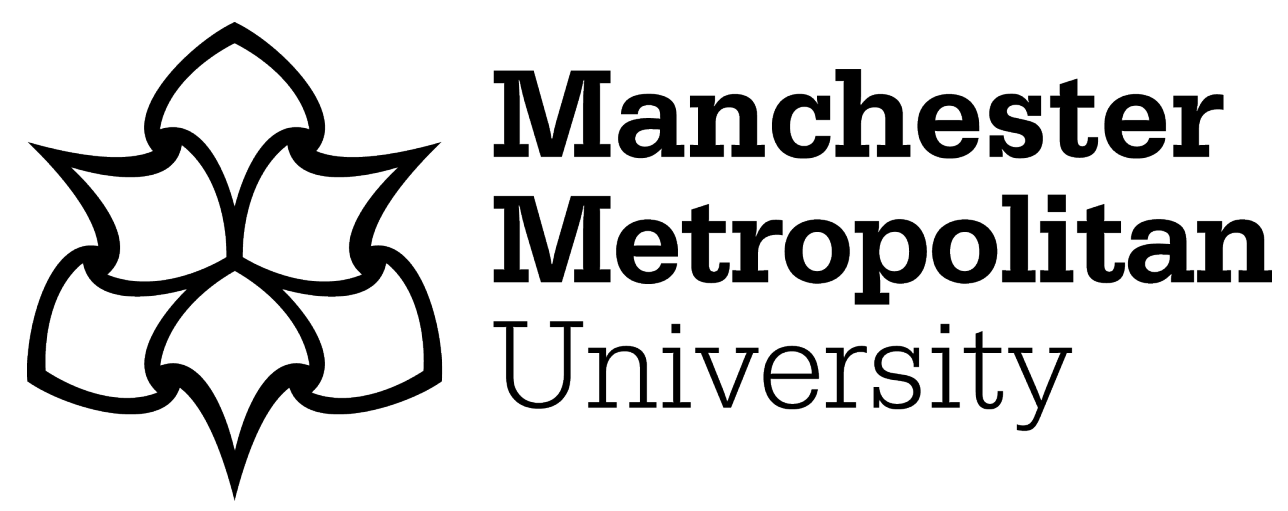

Ode-Ichakpa, Inalegwwu, Cleeve, Emmanuel ORCID logoORCID: https://orcid.org/0000-0001-8048-2115, Amadi, Chibuzo and Osemeke, Godswill (2020) A Business Case Argument for Corporate Social Responsibility Disclosure in Nigeria. Africa Journal of Management, 6 (4). pp. 407-418.

Downloaded from: https://e-space.mmu.ac.uk/622546/

Version: Accepted Version

Publisher: Taylor \& Francis

DOI: https://doi.org/10.1080/23322373.2020.1779450

Please cite the published version 


\section{A Business Case Argument for Corporate Social Responsibility Disclosure in Nigeria}

\section{Abstract}

From the theoretical perspectives of stakeholder, agency and slack resources, and using fixed effects and random effects models, this study investigates the relationship between Corporate Social Responsibility (CSR) and financial performance. The study adopts fixed and random effects panel estimates which deal with unobserved heterogeneity not addressed by OLS. The result is positive between CSR and Tobin's q. This strengthens the argument that CSR creates value for stakeholders. The implications of this study lie in the common knowledge that Nigerian companies should address CSR from a strategic context of meeting stakeholder needs, in addition to satisfying shareholder expectations. Given that Nigeria's economy by GDP is the largest in Africa, findings in this study would have far reaching implications from an African context.

Key words: CSR, Fixed \& Random Effects, Stakeholders, agency and slack resource.

\section{Introduction}

The relation between corporate social responsibility (CSR) and organisation performance has attracted much attention among researchers. Some studies have revealed a positive relationship (Mishra \& Suar 2010). Other studies have shown that there is a negative relationship and thus no business case to justify corporate social responsibility (Wright \& Ferris 1998). Another set of researchers have proved that there is no relationship between corporate social responsibility and organisation performance (Aupperle et al. 2014).

In spite of the high interest on the topic of CSR particularly concerning its relationship with financial performance, results of previous studies are indeterminate. It means that this area is riddled with inconclusiveness. This gap influences the study. Furthermore, previous researchers have focused more on profitability whereas organisational performance goes beyond short-term profits thus constituting gap in element. Most of the previous studies were conducted in foreign countries, indicating dearth of studies in African economies.

There are two reasons this study is important. Firstly, it is of particular relevance in fast developing regions of emerging economies like Nigeria given the profound impact that companies located in these regions have on the environment due to the enormous amount of energy they need (Achike \& Onoja 2014). Parry et al. (1998) explained that in countries where emissions is expected to occur, firms operating in these regions may resort to unethical practices because of incentive to achieve short-term financial results and sustain a global competitive edge. The economy of Nigeria is the largest in Africa, the country has an estimated population of 191 million which makes it the most populated country in the continent. The country's economy at a nominal GDP of over \$1 trillion in 2017 is larger than the combined economies of the other 14 countries in the Economic Community of West African States (ECOWAS) of which Nigeria is a member. This makes findings from research on Nigeria very relevant and applicable in the context of Africa as a whole.

Secondly, the study provides evidence of whether CSR in Nigeria is primarily perceived as altruistic and philanthropic, or whether Nigerian companies adopt it as a strategic tool for business success, or even as a mere box ticking exercise. The study goes further to establish using econometric models to determine whether there exists any business case justification for the adoption of corporate social responsibility. 
This discussion leads to the notion that the meaning and practice of CSR in Africa may differ from the traditional U.S. model (Visser, 2006, p. 195). Visser (2006) recognises that no comparative empirical study has been conducted, but speculatively argues that economic responsibilities still get the most emphasis as, given the continent's generally high unemployment, debt, and poverty, economic contributions are "highly prized." However, philanthropy is given second highest priority for three reasons.

Firstly, the socio-economic needs of the African societies in which organisations operate are so great that philanthropy is an expected norm. It is considered the right thing to do by business and the most direct way to improve the prospects of the communities in which business operates (Lindgreen, 2013).

Secondly, many African societies have become reliant on foreign aid. Visser (2012) explained that in 2002, Sub-Saharan Africa received about $\$ 19$ billion of official development assistance (ODA), which is equal to $\$ 28$ per capita, compared with an average of $\$ 11$ for the world. A study of philanthropy by U.S. Foundations revealed that in 2002, Sub Saharan Africa received around $\$ 150$ million from US grant makers alone. Hence, there is an embedded ethos of philanthropy in Africa.

Thirdly, Africa is generally still at an infant stage of maturity in CSR compared to the more embedded approaches now common in developed countries. Legal priorities are the next level in the African CSR pyramid. It is claimed that in Africa there is far less of a pressure for good conduct dictated by the law than in developed countries because of reasons such as a poorly developed legal infrastructure. Finally, drawing on global statistics on corruption in Africa, Visser (2006), suggests that, in practice, ethics remains the lowest CSR focus.

The remaining part of this paper is organized as follows: Section 2 discusses empirical literature and the basis of hypotheses, especially as they relate to the Nigerian CSR environment. In Section 3, we describe the sample data, CSR measurement; variables used and present the estimation models. Analysis of the results are presented in Section 4. In section 5, we present some implications of the study and in section, 6 summarise the study with conclusions.

\section{Conceptual and Empirical literature}

The relationship between CSR and financial performance provides some controversy along with a plethora of inconclusive empirical evidence. Donaldson and Preston (1995) explained that the traditional "principal agent" theory is untenable and proposed the Stakeholder theory as a veritable alternative. The Stakeholder theory proposes that management must take into cognisance a set of interest groups that transcends only shareholders (Jensen \& Meckling 1976). The Stakeholder Theory framework, opines that if consideration is given to the interests of the numerous stakeholders of the organisation, this may improve firm image and status, and that firm's focus on such interests are able to positively affect firm's productivity, financial performance and value creation (Hillman, A.; Keim 2001; Donaldson et al. 1995). Conversely, in spite of identifying the significance of customers and employees as genuine and important stakeholders of corporations argued that CSR is not capable of increasing firm value (Friedman 1970). Still in the same line of argument, other authors also claim that investments, or expenditures, in activities not related to the prime objective of the 
organisation constitutes diversions of resources from shareholders and from the main purpose of existence of the organisation. Moreover, it entails that the firm maintain some mechanism that will help in managing such activities that are deviations from its primary objective. Therefore, any of such added costs may add to economic drawbacks for the firm (Vance 1975; Ullmann 1985). The Agency Theory framework suggest that a negative effect of CSR on value creation could be anticipated considering that, the effort to satisfy the demands of an extended group of stakeholders may result in additional agency conflicts (Crisóstomo et al., 2011).It also proposes that CSR is an executive perquisite, in the sense that managers use CSR to further their careers or other personal agendas. Freeman (1984), building on Chester Barnard's (1938) 'inducement contribution' framework, presented a more positive view of managers' support of CSR (Friedman \& Miles 2001; Freeman \& McVea 2001; Barnard 1938). The Slack Resources Theory assumes that low-risk organisations are more involved than others in socially responsible activities. They have a steady profitability model and can therefore invest in social activities (Roberts 1992). The slack resource theory very much contrasts the views advanced by the stakeholder theory. This is because, whilst the stakeholder theory seems to consider the generality of the agents that have an effect on an organisation when addressing CSR, the slack resource theory focuses on addressing the needs and wants of owners of the business (shareholders) and then if there is anything left in terms of resources, only then are other stakeholders considered.

Despite the hope in the large number of studies that have proved the relationship between corporate social responsibility and organisation performance, Griffin \& Mahon (1997) opined that there exists a certain level of disparity and inconsistencies in the results arrived at when attempting to establish the relationship between corporate social responsibility and organisation performance. They explained that the reason for this lack of uniformity in the results stems from the ubiquitous disparity in conceptual, methodological and operationalization differences in the definition of social and financial performance (Andriof \& Waddock 2002). Perrini et al (2009), Margolis and Walsh (2003) counted 127 studies devoted to exploring the corporate social responsibility and organisation performance relationship in the period from 1972 to 2002. Their results were somewhat surprising: Despite the fact that the vast majority of research found a significant positive relationship, there were conflicting results even in cases based on the same sample of firms. As a result, the relationship should be recognised as, complex, and ambiguous, not allowing for much theoretical generalization on the strategic effect of responsible business conduct (Perrini et al., 2009). Majority of the studies investigated by Perrini et al. (2009) were carried out on developed economies which leaves a dearth of research in Africa. It opens an opportunity to explore this relationship from an African perspective. Although this current study's focus is on Nigerian listed firms, it has the potential of providing an outlook for CSR implementation across Africa. This is due to the fact that the Nigerian economy currently accounts for over $17 \%$ of the entire GDP of Africa making it the largest economy in the continent.

In the Nigerian context, the quest to unravel this relationship between CSR and financial performance has taken different forms. Some authors have focused on the banks; others have used insurance companies, manufacturing companies, SMEs, and listed companies. Quantifying CSR also took different dimensions as some used expenditure in CSR, investment in CSR and ranking CSR disclosures. Amole et al (2012) conducted a study on the impact of corporate social responsibility on the profitability of Nigerian banks, which utilised ordinary least square (OLS) model of regression in testing the relationship between dependent and 
independent variables. The study made use of data on funds spent on CSR activities and profit after tax for the period of 2001-2010. The metrics used for CSR seems narrow as profit after tax does not account for the non-monetary aspects which are not conventionally captured in a company's financial statement. Moreover, utilising data obtained only from banks could limit the scope of the study. Hossein et al. (2012) on the other hand examined the link between CSR and economic performance by examining different impacts of positive and negative CSR activities on financial performance of hotel, restaurant and airline companies, theoretically based on positivity and negativity effects. Findings suggest mixed results, the problem with this piece of work is that it focused so much on definitions and theoretical frameworks of CSR and paid little attention to the burning issue of whether there exist a relationship between CSR and financial performance. Babalola (2012), examined the relationship between corporate social responsibility and firms' profitability in Nigeria with the use of secondary data, sourced from ten (10) randomly selected firms' annual report and financial summary between "1999-2008." The weakness of the study is evident from the very limited number of companies used. The use of Ordinary least square does not address any endogeneity issues that could affect the results. Complete reliance on accounting performance metrics such as Profit after Tax is a drawback to this piece of work.

Luper (2013) showed that there is need for the Nigerian banks to rethink Corporate Social Responsibility (CSR) in all the key sectors (such as education, power, health, agriculture, and small and medium-sized enterprises) of the economy. The results of the descriptive statistics and sample t-test show that, bank consolidation in Nigeria has led to a decline in SMEs financing to less than one percent on average in the study period, and there is no significant improvement in SMEs financing in Nigeria before and after bank consolidation. The research ends with recommending that Nigerian banks should be involved in training owners of SMEs as a CSR gesture. Confining CSR to training assistance alone is quite narrow and does not examine the big picture of what CSR represents. The statistical tools utilised were also quite basic and did not show any form of relationship between CSR and financial performance. Uwuigbe \& Egbide (2012) looked at the relationship between firms' financial leverage and the level of corporate social responsibility disclosures among selected firms. The annual reports for the period 2008 were utilised as the main source of data collection for the sampled 41 listed firms, the multiple regression analysis was employed as a statistical technique for analyzing the data collected. The shortcoming of the study lies in the researcher's decision to only consider 2008 as a period.

The relevant CSR theories that are adopted in the current study are the agency, stakeholder and slack resource theories. The Agency theory suggests that CSR is a misappropriation of corporate wealth that would be better expended on valued-added internal projects or returned to shareholders (Friedman \& Miles 2001). The stakeholder approach to CSR assumes that the success of the firm depends on how well relationships with several important groups are managed, which comprise of customers, employees, suppliers, financiers and other important community organisations with which it cooperates. On each of these groups, including those with whom it has no legal contractual relation is seen as a group with some participation in the activities of the enterprise (Robins 2008; Robins 2005). The Slack Resources Hypothesis assumes that low-risk organisations are more involved than others in socially responsible activities. They have a steady profitability model and can therefore invest in social activities (Roberts, 1992). Based on the foregoing, the following hypotheses were developed: 
Hypothesis 1. There is a positive relationship between CSR and firm value.

The hypothesis supports the line of thought that long-term value creation can be achieved if companies focus on addressing CSR by taking into consideration all stakeholders that have an affinity with the firm. As would be revealed in subsequent parts of this paper, long-term value is represented using Tobin's q. The hypothesis is meant to examine the stakeholder theory of CSR.

Hypothesis 2. CSR negatively affects firm's financial performance.

The hypothesis supports the financial line of thought, advocating that the CSR expenditure are in all, a misapplication of resources considering that firm's main activities and that the group of Nigerian social stakeholders are not yet capable of considering firm's CSR as a decision benchmarks with regards to their alternatives for investment and consumption (Vance, 1975, Ullman, 1985, Friedman, 1970). The hypothesis is meant to examine the agency theory of CSR.

Hypothesis 3. Financial performance positively affects CSR.

The hypothesis examines the directional impact of financial performance on CSR. Whilst the above hypotheses examines the impact of CSR on financial performance, this hypothesis looks at it the other way round. The hypothesis is meant to examine the slack resource theory of CSR.

\section{Research methodology}

\subsection{The sample}

This study uses only secondary data that was gathered from the sampled companies' annual reports. The resulting panel was unbalanced. The firm is the primary stratification variable. The analysis covers 10-year period, period from 2005 - 2014 covering 30 Nigerian Stock Exchange (NSE) companies. Annual Reports were obtained from thirty companies over the ten year period.

\subsection{CSR Measures}

The problems in measuring CSR, as often reported, are yet more difficult in markets in which the question is still incipient, as it is the situation with countries with emerging markets. Nigerian firms are not obligated by law to disclose information about their social activities. Therefore, companies that choose to do it will act freely with no standard of structure or data disclosed. Voluntarily some companies have begun doing it. Nonetheless, such lack of consistency of format and specificity of data to be disclosed adds difficulty to this kind of research. The CSR index adopted in this study is based on GRI's information, which contains 
information regarding the three corporate dimensions: economics, social dimensions and environmental dimensions. The data, which has the virtue of being quantitative in nature, is derived by assigning one if there is adherence and zero for no adherence and then summed up to get the total score for each dimension and for overall CSR. These three dimensions of CSR have been used as proxies for CSR in a number of distinct previous works, in different manners, as has been depicted by Orlitzky et al. (2003) and Margolis and Walsh (2003).

\subsection{The Variables for Analysis}

The dependent variable for this empirical analysis is Tobin's q. Tobin's q has been looked at in this work as the market value of the firm, divided by the replacement value of its assets. Tobin's q has been used widely in economics, finance, and strategy as a performance measure (Morck et al. 1988, Waddock and Graves 1997). It captures how much value the firm creates with its asset base. The benefit of using Tobin's q over profitability is that profitability is a short-term measure, whereas Tobin's q is a long-term measure because it is based on the market value of the firm. This metric aligns with hypothesis 1 above.

On the other hand, Return on Equity has been adopted to test the second and third hypotheses. In face of the lack of a consensus and following the current tendency in the CSR literature, this work adopts return on equity (ROE) as the financial accounting performance measure which has been vastly used previously (Waddock and Graves, 1997, Baron et al., 2009). ROE as earlier stated is a short-term financial measure; the justification for the use of this ratio stems from the idea that CSR has an impact on stockholders of listed companies when it comes to making investment decisions. This metrics aligns with hypothesis 2 above. Hypothesis 3 simply changes the direction of causality in hypothesis 2 to explain the slack resource theory.

To ensure that the results are not compelled by firm heterogeneity, control variables were introduced that cover the firm's characteristics including size; indebtedness, as well as the company's sales growth. Other independent variables that have been included in our model are sector and time dummies.

This study uses two regression methods: fixed and random effect models. The choice between fixed effect and random effect is determined by the Hausman specification test. The researcher presumes a cross sectional fixed effect with constant in the current study and developed the following regression models for the analysis of the current study.

$$
\begin{aligned}
& \text { TOBIN'S } q_{i t}=\beta_{i}+\beta_{1} \text { CSR }_{i t}+\beta_{2} \text { SALEG }_{i t}+\beta_{3} \text { SIZE }_{i t}+\beta_{4} L_{V R G}+S_{i t}+\varepsilon_{1 i t} \\
& \mathrm{ROE}_{\mathrm{it}}=\boldsymbol{\lambda}_{i}+\boldsymbol{\lambda}_{1} \mathrm{CSS}_{\mathrm{it}}+\boldsymbol{\lambda}_{2} \mathrm{SALEG}_{\mathrm{it}}+\boldsymbol{\lambda}_{3} \mathrm{SIZE}_{\mathrm{it}}+\boldsymbol{\lambda}_{4} \mathrm{LVRG}_{\mathrm{it}}+\mathrm{SD}_{\mathrm{it}}+\varepsilon_{2 \mathrm{it}} \\
& \mathrm{CSR}_{i \mathrm{t}}=\mu_{i}+\mu_{1} \mathrm{ROE}_{\mathrm{it}}+\mu_{2} \mathrm{SALEG}_{\mathrm{it}}+\mu_{3} \mathrm{SIZE}_{\mathrm{it}}+\mu_{4} \mathrm{LVRG}_{\mathrm{it}}+\mathrm{SD}_{\mathrm{it}}+\varepsilon_{3 \mathrm{it}}
\end{aligned}
$$

Tobin's $q_{i t}$ is the dependent variable and proxy for firm value. 
Roeit is the dependent variable and proxy for short-term firm financial performance

Csri,t represents the Corporate Social Responsibility.

Salesg represents revenue growth rate in year $t$, measured as changes in revenue over two consecutive years divided by the previous year's revenue, where t ranged from 2005 to 2014 .

Lvrg is the firm's financial leverage, measured as total liabilities divided by total assets at the end of year $t$, where $t$ ranged from 2005 to 2014.

Size represents firm size measured as logarithm of total assets, at the end of year $t$, where $t$ ranged from 2005 to 2014.

$S d_{i t}$ Represents sector dummy. Since the companies used in this study fall under different sectors of the industry, it is necessary to control for industry effect. To do this, Industry dummy variables have been incorporated as explanatory variables.

$\varepsilon_{i t}$ is the random disturbance term (error term) that accounts for model specification errors.

\section{Results}

\subsection{Analysis for hypothesis 1}

Table 1 below show fixed effects results. The outcome variable as indicated in the table below is Tobin's q, which is the dependent variable and proxy for firm value. The predictor variables used are CSR, size (Intotal assets) natural logarithm of total asset, leverage and sales growth. In the fixed effect model, the errors $\mathbf{U}_{i}$ are correlated with the regressors.

The Hausman test result show a probability that is less than 0.05 . Therefore the appropriate panel estimate is fixed effects as the null hypothesis was rejected in favour of the alternate hypothesis. The $p$ value is 0.0000 which indicates that the model fits the data appropriately. It is also a test to determine if all the coefficients in the model are different from zero. Since the coefficients of the regressors indicates how the changes in Tobin's q changes when the independent variables increase by one unit, we can observe that there exists a positive relationship between Tobin's q and CSR at 183.2399. These findings largely support Hypothesis 1, and is consistent with the stakeholder theory. The logarithm of total assets, which represents size proxy, shows a negative relationship with Tobin's q at -60.35305 . This might mean that the smaller firms in our sample are the actual ones investing in and disclosing their CSR activities. Leverage has a positive relationship with Tobin's q at 25.42666. It could be an indication that companies with a certain level of debt profile tend to invest some funds in CSR activities. From an accounting perspective, borrowed funds usually have tax shield advantages (Kemsley \& Nissim 2002). Therefore, the conclusion can be made that some of the firms in this study tend to invest in CSR activities to probably help in reducing their tax liabilities. For instance investing in improving a community or even purchasing energy efficient equipment might help reduce tax as well as help to save other energy usage. Sales growth has a negative relationship with Tobin's q at -10.81533 . This might mean that increased sales, which should normally increase profits is not responsible for increased CSR. 
Perhaps, investing in CSR related activities help in cost reduction that eventually increase profits. The positive result between CSR and Tobin's $q$ is consistent with prior empirical findings (Servaes \& Tamayo 2013; Raza et al. 2014). The results of the regression estimates for CSR, SIZE, Leverage, and sales growth are significant at $0.000,0.000,0.114$ and 0.001 respectively.

Table 1: Fixed effects

\begin{tabular}{|l|l|}
\hline VARIABLES & \multicolumn{1}{|c|}{ TOBIN'S q } \\
\hline & Fixed Effects \\
\hline CSR & 183.2399 \\
\hline SIZE & -60.35305 \\
\hline LEVERAGE & 25.42666 \\
\hline SALESGROWTH & -10.81533 \\
\hline CONSTANT & 497.2477 \\
\hline INDUSTRY EFFECTS & YES \\
\hline YEAR EFFECTS & YES \\
\hline R 2 & 0.4362 \\
\cline { 2 - 2 } & 0.0924 \\
\cline { 2 - 2 } & 0.1250 \\
\hline P-Value & 0.0000 \\
\hline
\end{tabular}

\subsection{Analysis for hypothesis 2}

The Hausman test result shows a probability that is greater than 0.05 . Therefore, the appropriate panel estimate is random effects as the null hypothesis was accepted in favour of the alternate hypothesis. The $p$ value is 0.0008 which indicates that the result is significant and that the model fits the data appropriately. It can be observed that there exists a positive relationship between ROE and CSR at 12.17749. However, the level of significance in the results of the regression estimates for ROE, SIZE, Leverage, and sales growth are at 0.822 , $0.028,0.004$ and 0.076 respectively. Hypothesis 2 , therefore, is not supported.

Table 2: Random effect

\begin{tabular}{|c|c|c|}
\hline \multicolumn{2}{|c|}{ VARIABLES } & ROE \\
\hline & & Random Effects \\
\hline \multicolumn{2}{|c|}{ CSR } & 12.17749 \\
\hline \multicolumn{2}{|c|}{ SIZE } & -12.59449 \\
\hline \multicolumn{2}{|c|}{ LEVERAGE } & -67.93373 \\
\hline \multicolumn{2}{|c|}{ SALESGROWTH } & 12.72075 \\
\hline \multicolumn{2}{|c|}{ CONSTANT } & 135.5854 \\
\hline \multicolumn{2}{|c|}{ INDUSTRY EFFECTS } & YES \\
\hline \multicolumn{2}{|c|}{ YEAR EFFECTS } & YES \\
\hline \multirow[t]{2}{*}{$\mathbf{R}^{2}$} & Within & 0.0763 \\
\hline & Between & 0.1820 \\
\hline
\end{tabular}




\begin{tabular}{|l|l|l|}
\hline & Overall & 0.1111 \\
\hline P-Value & 0.0008 \\
\hline
\end{tabular}

\subsection{Analysis for hypothesis 3}

The researcher has decided to change the direction of the variables; this is consistent with previous literature (Waddock \& Graves 1997). In other words, ROE will be the independent variable and CSR is the dependent variable. The reasoning behind this is to test the slack resource theory of CSR, which explains that firms will only invest in CSR activities from excess cash flow.

The Hausman test result show a probability that is less than 0.05 . Therefore the appropriate panel estimate is fixed effects as the null hypothesis was rejected in favour of the alternate hypothesis. The $p$ value is 0.0000 which indicates that the model is significant and that the model fits the data appropriately. It can be observed that there exists a negative relationship between CSR and ROE at -.0000882. The level of significance in the results of the regression estimates for ROE, SIZE, Leverage, and sales growth are at $0.364,0.000,0.073$ and 0.114 respectively. Hypothesis 3 , therefore, is not supported.

Table 3: Fixed effect

\begin{tabular}{|c|c|c|}
\hline \multicolumn{2}{|c|}{ VARIABLES } & CSR \\
\hline & & Fixed Effects \\
\hline \multicolumn{2}{|c|}{ ROE } & -.0000986 \\
\hline \multicolumn{2}{|c|}{ SIZE } & .0544332 \\
\hline \multicolumn{2}{|c|}{ LEVERAGE } & .0689897 \\
\hline \multicolumn{2}{|c|}{ SALESGROWTH } & -.0135954 \\
\hline \multicolumn{2}{|c|}{ CONSTANT } & -.4189906 \\
\hline \multicolumn{2}{|c|}{ INDUSTRY EFFECTS } & YES \\
\hline \multicolumn{2}{|c|}{ YEAR EFFECTS } & YES \\
\hline \multirow[t]{3}{*}{$\mathbf{R}^{2}$} & Within & 0.2729 \\
\hline & Between & 0.0636 \\
\hline & Overall & 0.0438 \\
\hline \multicolumn{2}{|c|}{ P-Value } & 0.0000 \\
\hline
\end{tabular}

\section{Conclusion}

This study demonstrate that CSR has a degree of influence on firm value, thereby upholding a business case argument from a stakeholder perspective. No clear support for the agency theory or slack resources theory of CSR were found, however. CSR does appear to affect longer-term value rather than being associated with short-term performance. 
This empirical study contributes to CSR literature from the context of developing countries. It could help to improve corporate governance and social disclosure frameworks related to environmental, energy, employee, community and products or customer concepts of the developing countries in which they operate. It is important to improve future research in understanding the CSR framework and the association between CSR disclosure and financial performance.

The investigation of the theories in the Nigerian situation adds to the body of knowledge for developing countries. Consequently, the theory and findings of this study develop our understanding of the stakeholder, agency, and slack resource theories and provide consciousness into the nature of CSR activity in PLCs in Nigeria.

The result validates the assumption that CSR should be addressed from a position whereby organisations continually ensure that they are meeting the requirements and expectations of not just the shareholders but to also ensure that stakeholders are adequately taken care of. This is in line with the views of the stakeholder theory (Hirigoyen \& Poulain-Rehm 2015b; Ross \& Crossan 2012; Friday 2015).

\section{References}

1. Achike, A.I. and Onoja, A.O. (2014) 'Greenhouse gas emission determinants in Nigeria: implications for trade', Climate Change Mitigation and Adaptation Policies, Vol 4, no. 1, pp.83-94.

2. Amole, B. B., Adebiyi, S. O. \&Awolaja, A. M. (2012). Corporate social responsibility and Profitability of Nigeria banks - A causal relationship. Research Journal of Finance and Accounting, 3(1), 6-17.

3. Andriof, J. \& Waddock, S. a., 2002. Unfolding stakeholder engagement. Unfolding Stakeholder Thinking: Theory, Responsibility and Engagement, Vol. 1, pp.17-42. 
4. Aupperle, K.E. et al., 2014. An Empirical Examination of the Relationship between Corporate. Academy of Management Journal, 28(2), pp.446-463.

5. Babalola, Y. (2012), "The Impact of Corporate Social Responsibility on Firm's Profitability in Nigeria". European Journal of Economics, Finance and Administrative Science, Vol.45, pp. $39-50$.

6. Barnard, C., 1938. Informal Organizations and their Relation to Formal Organizations. In Classics of public administration. P. Ch. 11.

7. Baron, D. P., Harjoto, M. A. \& JO, H. 2009. The Economics and Politics of Corporate Social Performance. Stanford University Graduate School of Business Research Paper No. 1993; Rock Center for Corporate Governance at Stanford University Working Paper No. 45.

8. Crisóstomo, Vicente Lima., Fátima de Souza Freire, and Felipe Cortes de Vasconcellos. (2011), "Corporate social responsibility, firm value and financial performance in Brazil", Social Responsibility Journal, 7 (Iss: 2) 295 - 309. https://doi.org/10.1108/17471111111141549

9. Donaldson, T., Preston, L.E. \& Preston, L.E.E.E., 1995. The Stakeholder Theory of the Corporation: Concepts, Evidence, Corporations and its Implications. Academy of Management Review, 20(1), pp.65-91

10. Freeman, R. Edward 1984 Strategic management: A stakeholder approach. Marshfield, MA: Pitman.

11. Freeman, R.E. \& McVea, J., 2001. Darden Graduate School of Business Administration A Stakeholder Approach to Strategic Management. Working Paper, (1).

12. Friday, O.B., 2015. The International Journal of Business \& Management. The Role of Corporate Social Responsibility and Its Relevance in the Nigerian Oil Industry. , 3(11), pp.222-230.

13. Friedman, A.L. \& Miles, S., 2001. Socially Responsible Investment and Corporate Social and Environmental Reporting in the UK: An Exploratory Study. The British Accounting Review, 33(4), pp.523-548. https://doi.org/10.1006/bare.2001.0172

14. Friedman, M., 1970. A Friedman Doctrine--The Social Responsibility of Business Is to Increase Its Profits. New York Times Magazine, 33, p.126.

15. Griffin, J.J. \& Mahon, J.F., 1997. The Corporate Social Performance and Corporate Financial Performance Debate. Business \& Society, 36(1), pp.5-31.

16. Hillman, A.; Keim, G.D., 2001. Shareholder Value, Stakeholder Management, and Social Issues: What's the Bottom Line? Strategic Management Journal, 22(2), pp.125139.

17. Hirigoyen, G. \& Poulain-Rehm, T., 2015a. Relationships between Corporate Social Responsibility and Financial Performance: What is the Causality? Journal of Business and Management, 4(1), pp.18-43. https://doi.org/10.12735/jbm.v4i1p18

18. Hossein, K., Kamran, N., Mostafa, E., and Hossein, A. (2012). Impact of Corporate Social Responsibility Activities on Company Performance. Interdisciplinary Journal of Contemporary Research in Business. , Vol 3, No 9 pp. 583-592.

19. Jensen, M.C. \& Meckling, W.H., 1976. Theory of the Firm: Managerial. Journal of Financial Economics, 3, pp.305-360. 
20. Kemsley, D. \& Nissim, D., 2002. Valuation of the debt tax shield. Journal of Finance, 57(5), pp.2045-2073.

21. Lindgreen, A., 2013. Social Responsibility Corporate in Developing and Transitional Practices Countries: Botswana and Malawi. , Journal of Business Ethics, pp.429-440. https://doi.org/10.1007/s10551-010-0415-3

22. Luper, I., 2013. Rethinking Banks Corporate Social Responsibility (CSR) in Nigeria. International Journal of Finance and Accounting, 2(1), pp.30-36.

23. Margolis, J. and J. Walsh: 2003, 'Misery Loves Companies: Rethinking Social Initiatives by Business', Administrative Science Quarterly 48, 268-305.

24. Mishra, S. \& Suar, D., 2010. Does corporate social responsibility influence firm performance of Indian companies?

25. Morck R, Shleifer A, Vishny RW (1988) Management owner- ship and market valuation: An empirical analysis. J. Financial Economy. 20:293-315.

26. Orlitzky, M., F. Schmidt and S. Rynes: 2003, 'Corporate Social and Financial Performance: A Meta-Analysis', Organization Studies 24, 403-441.

27. Parry, M., N. Arnell, M Hulme, R. Nicholls and M. Livermore: 1998, 'Adapting to the inevitable', Nature 395, 741.

28. Perrini, F. A. Russo, A. Tencanti and C. Vurro (2009), Going beyond a long-lasting debate: What is the relationship between corporate social and financial performance?', Sustainable Value', EABIS research project working paper.

29. Raza, A., Ilyas, M. I., Rauf, R. and Qamar, R. (2012), "Relationship between Corporate Social Responsibility (CSR) and Corporate Financial Performance (FP): Literature review approach", Elixir Financial Management, Vol.46 No. 9, pp. $8404-8409$

30. Robins, F., 2005. The Future of Corporate Social Responsibility. Asian Business \& Management, 4(2), pp.95-115.

31. Robins, F., 2008. Why corporate social responsibility should be popularised but not imposed. Corporate Governance: The international journal of business in society, 8(3), pp.330-341.

32. Roberts, R.W., 1992. Determinants of corporate social responsibility disclosure: an application of stakeholder theory. Accounting, Organizations and Society, 17(6), pp.595-612.

33. Ross, A. \& Crossan, K., 2012. A review of the influence of corporate governance on the banking crises in the United Kingdom and Germany. Corporate Governance: The international journal of business in society, 12(2), pp.215-225.

34. Servaes, H. \& Tamayo, A., 2013. The Impact of Corporate Social Responsibility on Firm Value : The Role of Customer Awareness The Impact of Corporate Social Responsibility on Firm Value: The Role of Customer Awareness. Management Science, 59(5), pp.1045-1061.

35. Ullmann, A.A., 1985. Data in Search of a Theory: A Critical Examination of the Relationships among Social Performance, Social Disclosure, and Economic Performance of U.S. Firms. Academy of Management Review, 10(3), pp.540-557. https://doi.org/10.5465/amr.1985.4278989 
36. Uwuigbe, U., \& Egbide, B. C. (2012). Corporate social responsibility disclosure in Nigeria: A study of listed financial and non-financial firms. Journal of Management and Sustainability, 2(1).

37. Vance, S.C., 1975. Are Socially Responsible Corporations Good Investment Risks? Management Review, 64(8), pp.18-24.

38. Visser, W. (2006). Revisiting Carroll's CSR pyramid. In: E.R. Pedersen and Huniche, M. (Eds), Corporate Citizenship in Developing Countries, the Copenhagen Centre. Available at http://www.waynevisser.com/chapter_wvisser_africa_csr_pyramid.pdf (accessed 25-01-2011) Wood,

39. Visser, W. (2012). The Future of CSR: Towards Transformative CSR, or CSR 2.0. Available at http://ssrn.com/abstract $=2208101$

40. Waddock, S.A. \& GRAVES, S.B., 1997. The Corporate Social Performance-Financial Performance Link. Strategic Management Journal, 18(4), pp.303-319.

41. Wright, P. \& Ferris, S.P., 1998. Research Notes and Communications Agency Conflict and Corporate S. Strategic Management Journal, 18(November 1994), pp.77-83. https://doi.org/10.1002/(SICI)1097-0266(199701)18:1<77::AID-SMJ810>3.0.CO;2-R 